\title{
Moving beyond self-castigation: let's reinvigorate communication policy research now!
}

\author{
Just, Natascha ; Puppis, Manuel
}

\begin{abstract}
Communication policy researchers have eagerly joined communication scholars in continuing selfconscious debates regarding their theoretical status and practical significance. They have done so to the point of earnest self-castigation and by unjustly denigrating their work. Given the current critical junctures for communications, this research field cannot remain in this state. It is high time to move beyond self-castigation and reinvigorate communication policy research by acknowledging its much-needed voice, recognizing its merits, and highlighting areas in need of advance.
\end{abstract}

DOI: https://doi.org/10.1093/joc/jqx012

Posted at the Zurich Open Repository and Archive, University of Zurich

ZORA URL: https://doi.org/10.5167/uzh-168190

Journal Article

Accepted Version

Originally published at:

Just, Natascha; Puppis, Manuel (2018). Moving beyond self-castigation: let's reinvigorate communication policy research now! Journal of Communication, 68(2):327-336.

DOI: https://doi.org/10.1093/joc/jqx012 


\title{
Moving Beyond Self-Castigation:
}

\section{Let's Reinvigorate Communication Policy Research Now!}

Natascha Just \& Manuel Puppis

\begin{abstract}
Accepted manuscript: Just, N. \& Puppis, M. (2018). Moving Beyond Self-Castigation: Let's Reinvigorate Communication Policy Research Now! In: Journal of Communication, 68(2), 327-336.
\end{abstract}

\begin{abstract}
Communication policy researchers have eagerly joined communication scholars in continuing self-conscious debates regarding their theoretical status and practical significance. They have done so to the point of earnest self-castigation and by unjustly denigrating their work. Given the current critical junctures for communications, this research field cannot remain in this state. It is high time to move beyond self-castigation and reinvigorate communication policy research by acknowledging its much-needed voice, recognizing its merits, and highlighting areas in need of advance.
\end{abstract}

Keywords: communication policy, media policy, research traditions, history of the discipline, current status 


\section{Moving Beyond Self-Castigation: \\ Let's Reinvigorate Communication Policy Research Now!}

For decades communication scholars have shown an awkward and relentless liking for selfanalysis regarding their influence or lack of it, as strikingly exemplified by the preceding Ferment in the Field discussions in this journal. Communication policy researchers have eagerly joined in this chorus to the point of earnest self-castigation, mooting whether they were only theoretically practical, if at all, but practically irrelevant (Just \& Puppis, 2012a). They have repeatedly and self-critically reassured themselves of their marginal contribution to communication policy-making, their lack of a real-world role (Noam, 1993), and their ceding of the field to other disciplines (Mueller, 1995; Bauer, Kim, Mody, \& Wildman, 2005) - a sentiment that has been echoed both throughout the West and in developing countries (Das \& Parthasarathi, 2011). Especially the consistently reiterated rift between administrative and critical research (Lazarsfeld, 1941) has sparked fruitless infighting and weakened the research field as a whole. In particular, this narrative helped fuel deceptive claims that communication policy research is mainly normative, non-empirical and descriptive, and consequently offers few insights for policy-makers. Altogether, undifferentiated generalized criticism has prevailed, obscuring much of communication policy research's wider merits and contributions. In particular, critical political economy has received an extensive share of criticism to the point of misrepresentation (Hardy, 2014), whereas more positivistic approaches have been more successful in depicting themselves as objective, impartial and value free. A latest example of this is Picard's (2016) selective account of the state of communication policy research, in which he rehashes the well-known accusations of it being disparate and incohesive, as well as weakened 
by disciplinary narrowness and dogged normative preference. Such general and often unsubstantiated criticism has been left unchallenged or similarly consented to, resulting in apparent tacit acceptance and at the same time undeserved self-conscious states of mind. Given the current critical junctures for communications (McChesney, 2009), this research field cannot remain in this state. It is therefore high time to reinvigorate communication policy research and move from self-consciousness to self-confidence (Just \& Puppis 2012a) by acknowledging its much-needed voice, recognizing its merits and highlighting where advances are still imperative.

\section{Knowledge for Critical Junctures}

While the idea of researching communications policy dates back to the mid $19^{\text {th }}$ century (Braman, 2003c), it was only from the 1970s that one started to speak of a research field (Pool, 1974). This institutionalization was connected to a growing need for insights for policy-makers due to technological, political and economic developments. In the following decades the changes in the media and communications sector have further intensified with convergence (Latzer, 1998), liberalization (Gibbons \& Humphreys, 2012) and globalization (Flew, 2007), giving way, among other things, to transformations of media markets and concentration processes (Baker, 2007; Noam, 2009; Just, 2009) or new forms of governance like the delegation of regulatory responsibilities from nation states to independent regulatory agencies, self-regulatory organizations as well as to supra-, inter- and transnational fora (Drake \& Wilson, 2008; Schulz, Valcke, \& Irion, 2013). Enormous changes in the communications sector are still continuing, including the various policy, regulatory and economic challenges of the Internet age (Mueller, 2010; Mansell, 2012; Bauer \& Latzer, 2016), for example the rise of global platforms (Bauer, 
2014; Gillespie, 2010), the surveillance practices of the informational state (Braman, 2006), or the growing governing power of technology/algorithms (Just \& Latzer, 2016). These changes also have significant implications for legacy media, including the role of public service media in the era of the Internet (Burri, 2015; Iosifidis, 2010) and the future of journalism (Curran, 2010; McChesney, 2008).

How all these developments unfold and how they will affect our societies will not least be determined by crucial policy decisions (McChesney, 2009). Arguably, policy-makers and regulators require scientific knowledge more than ever, and communication policy research may offer a much-needed voice in policy debates. It can contribute to better-informed policy-making (Braman, 2003a; Just \& Puppis, 2012a) and help counter the rise of populism and authoritarian politics by providing knowledge and showing alternative courses of action. There are sufficient grounds for self-confidence for this pledge to be kept.

\section{Grounds for Self-Confidence}

Although it is often contested, there is a solid basis from which to build and many grounds for self-confidence, as evidenced by the many enhancements that have occurred over the past four decades since communication policy research has become more institutionalized. The conflicts between administrative and critical research traditions that characterized the Journal of Communication's first "Ferment in the Field" of 1983 (Nordenstreng, 2004; Napoli \& Friedland, 2016) have largely subsided. Only ten years later, fewer authors were calling for communication policy scholars to engage more with policy-making (e.g., Noam, 1993). In 2005, then, Reinard and Ortiz (2005) self-confidently asserted that the study of communication law and policy had become an important area of research and theory in communication and matured to a point where 
the criticism that such research is too problem-driven, descriptive, focused on regulations and only slightly related to theory is gradually subsiding. Within the ICA (International Communication Association), IAMCR (International Association for Media and Communication Research) and ECREA (European Communication Research and Education Association) specialist sections, divisions and working groups are focusing on policy issues, putting an emphasis on theoretical and empirical work. In addition to individual studies, over the last ten years a number of high-quality edited volumes have reinvigorated the field by pushing its boundaries and strengthening its theoretical and methodological foundations (e.g., Donders, Pauwels, \& Loisen, 2014; Just \& Puppis, 2012b; Löblich \& Pfaff-Rüdiger, 2013; Mansell \& Raboy, 2011; Price, Verhulst, \& Morgan, 2013; Simpson, Puppis, \& Van den Bulck, 2016). The field of communication policy research has thus made significant progress - a development that would not have been possible without leaving "the turf wars" (Napoli \& Friedland, 2016, p. 53) between administrative and critical research behind. There is now a consensus that the separation into these two research traditions has often been misunderstood and overplayed. As a matter of fact, Lazarsfeld's (1941) seminal essay can already be seen as a "peace-making overture" (Katz \& Katz, 2016, p. 9) and a "call for better integration of these research traditions" (Napoli \& Friedland, 2016, p. 42). Moreover, and unlike sometimes suggested, Lazarsfeld never regarded the distinction as one between empirical and non-empirical research (Braman, 2003b). Especially with regard to communication policy research, it can be argued that the distinction between these traditions has always been blurred (Napoli \& Friedland, 2016). If anything, they mainly differ with respect to their selection of relevant problems and the questions asked at the beginning of the research process in the context of discovery (Just \& Puppis, 2012a), with a significant difference lying "in the allegiance of researchers to the status quo versus change" 
(Melody \& Mansell, 1983, pp. 109-110). Some scholars, for instance, will attach greater value to economic freedom; others stress the importance of basic democratic values like the distribution of power (e.g., Baker, 2007). These value conflicts are mirrored in communication policymaking, which - due to the dual character of media as simultaneously economic and cultural goods - is inherently value-laden (Just, 2009), therefore making communication policy issues

perhaps less amenable to straightforward, one-size-fits-all scholarly appraisal. But these conflicts can also lead to fruitful academic and policy debates, at least if scholars refrain from unsubstantiated attacks on each other's work and instead elaborate further on the field's theoretical and methodological foundations.

\section{Reinvigorating Communication Policy Research}

Reinvigorating communication policy research implies restoring its reputation by speaking up for it and acknowledging its merits and advances, but also pointing to areas where enhancements are still needed. As argued elsewhere (Just \& Puppis, 2012a), this involves a detailed grounding in theories and methods as well as researching subjects that matter.

A theory-driven approach to communication policy research is essential. Despite some claims that the field remains weak in theoretical terms and ignorant of wider policy research (Picard, 2016), there are significant developments with respect to theory development and application. By both reassessing established approaches and reaching out to new ones that are not commonly used in communication policy research, the research field is now more connected with the larger body of social theory (McQuail, 1994), which is a prerequisite for investigating fundamental questions about media, communication and policy in contemporary societies (Fuchs, 2017). Scholars have increasingly come to make use of theories that can explain how interests, 
institutions and ideas influence policy-making and its outcomes (e.g., contributions in Just \& Puppis, 2012b), and thus, for instance, apply critical theoretical approaches (e.g. Freedman, 2008), or variants of new institutionalism for understanding communication policy, politics and polity, regulation and the emergence of new governance arrangements (Bannerman \& Haggart, 2015; Latzer, Just, Saurwein, \& Slominski, 2003; Puppis, 2010). Moreover, the impact of convergence and growing complexity on communication policy strategies is assessed with recourse to a combination of innovation, coevolution and complexity theories (Latzer, 2014). Researchers also draw inspiration from critical regionalism (Ali, 2017), political philosophy (Schejter \& Tirosh, 2016), media history (Pickard, 2015; Zajácz, 2012), gender (Gallagher, 2011) and post-colonial studies (Alhassan \& Chakravartty, 2011). Advancing theoretically inevitably requires moving off the beaten paths and exploring new avenues from which insights may be gained. What is required concurrently and what is largely missing, however, is a discourse about the adequacy of certain theoretical approaches and their added value. An example of such discourse is the discussion of the Western disciplinary roots and traditions of communication research and concurrent calls for theories originating from other regions of the world (Waisbord \& Mellado, 2014; Wasserman \& de Beer, 2009).

In order to be credible in academia and beyond, methodological rigor is similarly indispensable. A few years ago we complained that - despite the field's self-conscious tradition methodological approaches are seldom explicated and discussions of methodological questions are virtually non-existent (Just \& Puppis, 2012a). The problem was never a lack of empirical research but a lack of discussion, explanation and scrutiny of the methods of data collection and data analysis used. This is increasingly being acknowledged by scholars and in more and more articles, books and presentations they are putting an emphasis on their methodological 
approaches. With articles focusing on the practicalities of interviews, document analysis and comparisons in communication policy research, the most frequently used methods in the field have received some much-deserved attention (Herzog \& Ali, 2015; Karppinen \& Moe, 2012; Puppis \& d'Haenens, 2012). Further, a new handbook will be devoted exclusively to research methods (Van den Bulck, Puppis, Donders, \& Van Audenhove, forthcoming). Despite such progress, it still cannot be taken for granted that studies will pay close attention to methods or that methods match research questions. A particular danger - afforded also by the new technical ease of (big) data collection - lies in following a quest for innovative approaches that are often not employed because of methodological necessity but because it is fashionable or "innovative" to do so. One of the biggest challenges for the field is therefore keeping up with new methods of studying the Internet and its policy implications while at the same time avoiding superficial analysis. Analyzing big data gathered from websites and social networks does indeed require new skills. However, "digital methods do not outdate but require traditional methods in order to avoid the pitfall of digital positivism" (Fuchs, 2017, p. 43).

As for choosing subjects that matter, scholars are faced with the difficulty that they need "to anticipate the pressing issues several years into the future" (Bauer et al., 2005, p. 21). In order to do research that affects people's everyday lives, it is pertinent to stay in touch with relevant actors and debates (Pickard, 2013). This involves talking to policy-makers, regulators and industry representatives, continuously monitoring the work of policy-making institutions and keeping track of developments that affect the media and communication industries as well as audiences in their roles as citizens and consumers. Technological, political, economic and social changes not only make it necessary to revisit old subjects, for example the role and transition of legacy media, the future of journalism as well as intellectual property or privacy, but also give 
rise to new subjects that need attention, for example algorithms, the power of platforms, or net neutrality. Moreover, scholars should not simply stick with individual policies but keep track of the wider interlocking of economic, social and political powers that both underpin and are afforded by the operations of the media industries (McChesney, 2008; Freedman, 2014), including the new Internet players. Furthermore, there is a need to expand on issues of global media policy (Iosifidis, 2011; Mansell \& Raboy, 2011; Raboy \& Padovani, 2010), the understanding of media and political systems beyond the West (Curran \& Park, 2000; Voltmer, 2012), and to scrutinize communication policy, development and democratization in countries of the global South (Flew, Iosifidis, \& Steemers, 2016; Flew \& Waisbord, 2015; Guerrero \& Márquez-Ramírez, 2014).

\section{Make it so!}

Evidently, communication policy research has reason to be more self-confident given the significant theoretical and methodological headway made when analyzing subjects both old and new. However, self-confidence should not foster self-delusion. As indicated above, a lot still needs to be done in order to continue the reinvigoration of the field with respect to theories, methods and subjects.

Scholars are increasingly trying to bring their findings into policy-making and by doing so, live up to Lasswell's (1970) definition of the policy sciences as both knowledge of the policy process as well as knowledge in this process. The extent to which policy-makers indeed pay attention to "evidence" and how research findings are chosen also needs to be scrutinized more thoroughly. Furthermore, forging the field's identity includes establishing ties with other fields of communication studies. Communication policy scholars perform research on policy issues and 
thus are naturally inclined to believe that their work is policy-relevant. Yet any research within communication studies can potentially inform communication policy-making (Kunkel \& Farinola, 2001). Given the proliferation of media-related challenges facing today's societies, researchers from different traditions and fields in communication studies can contribute valuable knowledge (McChesney, 2009; Pickard, 2013). Indeed, many scholars already contribute to policy research without identifying themselves as policy scholars or without necessarily realizing that they are performing policy-relevant work. Pursuing cooperation beyond the research field will accordingly add to its richness.

Looking back on the recent advances in communication policy research, Napoli and Friedland (2016) are hopeful that the next generation of scholars will be better trained in theories and methods and will have a more holistic view of the relationship between research and policymaking. We tend to agree - but anticipate that it will be hard work. Evidently then, even when advocating a move beyond self-castigation, communication policy researchers are not in danger of becoming uncritical of their own field.

\section{References}

Alhassan, A., \& Chakravartty, P. (2011). Postcolonial Media Policy Under the Long Shadow of the Empire. In R. Mansell \& M. Raboy (Eds.), The Handbook of Global Media and Communication Policy (pp. 366-382). Malden: Wiley Blackwell.

Ali, C. (2017). Media Localism. Urbana: University of Illinois Press.

Baker, C. E. (2007). Media Concentration and Democracy. Cambridge: Cambridge University Press. 
Bannerman, S., \& Haggart, B. (2015). Historical Institutionalism in Communication Studies. Communication Theory, 25(1), 1-22. doi:10.1111/comt.12051

Bauer, J. M. (2014). Platforms, systems competition, and innovation: reassessing the foundations of communications policy, Telecommunications Policy 38(8-9), 662-673. doi:10.1016/j.telpol.2014.04.008

Bauer, J. M., \& Latzer, M. (Eds.). (2016). Handbook on the Economics of the Internet. Cheltenham: Edward Elgar.

Bauer, J. M., Kim, S., Mody, B., \& Wildman, S. S. (2005, May 26-30). The Role of Research in Communications Policy: Theory and Evidence. Paper presented at the $55^{\text {th }}$ Annual ICA Conference, New York.

Braman S. (2003c). Policy as a Research Context. In S. Braman (Ed.), Communication Researchers and Policy-Making (pp. 35-58). Cambridge: MIT Press.

Braman, S. (2003a). Introduction. In S. Braman (Ed.), Communication Researchers and PolicyMaking (pp. 1-9). Cambridge: MIT Press.

Braman, S. (2003b). The Long View. In S. Braman (Ed.), Communication Researchers and Policy-Making (pp. 10-31). Cambridge: MIT Press.

Braman, S. (2006). Change of State. Cambridge: MIT Press.

Burri, M. (2015). Public Service Broadcasting 3.0. London: Routledge.

Curran, J. (2010). The Future of Journalism. Journalism Studies, 11(4), 464-476. doi:10.1080/14616701003722444

Curran, J., \& Park, M.-J. (Eds.). (2000). De-Westernizing Media Studies. London/New York: Routledge. 
Das, B., \& Parthasarathi, V. (2011). Media Research and Public Policy. In R. Mansell \& M. Raboy (Eds.), The Handbook of Global Media and Communication Policy (pp. 245-260). Malden: Wiley Blackwell.

Donders, K., Pauwels, C., \& Loisen, J. (Eds.). (2014). The Palgrave Handbook of European Media Policy. Basingstoke: Palgrave Macmillan.

Drake, W. J., \& Wilson, E. J. (Eds.) (2008). Governing Global Electronic Networks: International Perspectives on Policy and Power. Cambridge: MIT Press.

Flew, T. (2007). Understanding Global Media. Basingstoke: Palgrave Macmillan.

Flew, T., \& Waisbord, S. (2015). The ongoing significance of national media systems in the context of media globalization. Media, Culture \& Society, 37(4), 620-636. doi:10.1177/0163443714566903

Flew, T., Iosifidis, P., \& Steemers, J. (Eds.). (2016). Global Media and National Policies. Basingstoke: Palgrave Macmillan.

Freedman, D. (2008). The Politics of Media Policy. Cambridge: Polity Press.

Freedman, D. (2014). Media Policy Research and the Media Industries. Media Industries Journal, 1(1), 11-15.

Fuchs, C. (2017). From digital positivism and administrative big data analytics towards critical digital and social media research! European Journal of Communication, 32(1), 37-49. doi:10.1177/0267323116682804

Gallagher, M. (2011). Gender and Communication Policy: Struggling for Space. In R. Mansell \& M. Raboy (Eds.), The Handbook of Global Media and Communication Policy (pp. 451466). Malden: Wiley Blackwell. 
Gibbons, T., \& Humphreys, P. (2012). Audiovisual Regulation under Pressure. New York: Routledge.

Gillespie, T. (2010). The politics of 'platforms'. New Media \& Society 12(3), 347-364. doi: $10.1177 / 1461444809342738$

Guerrero, M. A., \& Márquez-Ramírez, M. (Eds.). (2014). Media Systems and Communication Policies in Latin America. Basingstoke: Palgrave Macmillan.

Hardy, J. (2014). Critical Political Economy of Communications: A mid-term review. International Journal of Media \& Cultural Politics, 10(2), 189-202. doi:10.1386/macp.10.2.189_1

Herzog, C., \& Ali, C. (2015). Elite interviewing in media and communications policy research. International Journal of Media \& Cultural Politics, 11(1), 37-54. doi:10.1386/macp.11.1.37_1

Iosifidis, P. (Ed.) (2010). Reinventing Public Service Communication. Basingstoke: Palgrave Macmillan.

Iosofidis, P. (2011). Global Media and Communication Policy. Basingstoke: Palgrave Macmillan.

Just, N. (2009). Measuring media concentration and diversity: new approaches and instruments in Europe and the US. Media, Culture \& Society, 31(1), 97-117. doi: $10.1177 / 0163443708098248$

Just, N., \& Latzer, M. (2016). Governance by Algorithms: Reality Construction by Algorithmic Selection on the Internet. Media, Culture \& Society, Published online before print April 21, 2016, doi:10.1177/0163443716643157. 
Just, N., \& Puppis, M. (2012a). Communication Policy Research: Looking Back, Moving Forward. In N. Just \& M. Puppis (Eds.), Trends in Communication Policy Research (pp. 9-29). Bristol: Intellect.

Just, N., \& Puppis, M. (Eds.). (2012b). Trends in Communication Policy Research. Bristol: Intellect.

Karppinen, K., \& Moe, H. (2012). What We Talk about When We Talk about Document Analysis. In N. Just \& M. Puppis (Eds.), Trends in Communication Policy Research (pp. 177-193). Bristol: Intellect.

Katz, E., \& Katz, R. (2016). Revisiting the Origin of the Administrative Versus Critical Research Debate. Journal of Information Policy, 6, 4-12. doi:10.5325/jinfopoli.6.2016.0004

Kunkel, D., \& Farinola, W. J. M. (2001). Underestimating Our Own Weight? The Scope and Impact of Communication Research on Public Policy. In W. B. Gudykunst (Ed.), Communication Yearbook 24 (pp. 411-431). Thousand Oaks: Sage.

Lasswell, H. D. (1970). The Emerging Conception of the Policy Sciences. Policy Sciences, 1(1), 3-14. doi:10.1007/BF00145189

Latzer, M. (1998). European Mediamatics Policies: Coping with Convergence and Globalization. Telecommunications Policy, 22(6), 457-466.

Latzer, M. (2014). Convergence, Co-evolution and Complexity in European Communications Policy. In K. Donders, C. Pauwels, \& J. Loisen (Eds.), The Palgrave Handbook of European Media Policy (pp. 36-53). Basingstoke: Palgrave Macmillan.

Latzer, M., Just, N., Saurwein, F., \& Slominski, P. (2003). Regulation Remixed: Institutional Change through Self and Co-Regulation in the Mediamatics Sector. Communications \& Strategies, 50, 127-157. 
Lazarsfeld, P. F. (1941). Remarks on Administrative and Critical Communication Research. Studies in Philosophy and Science, 9, 2-16.

Löblich, M., \& Pfaff-Rüdiger, S. (Eds.). (2013). Communication and Media Policy in the Era of the Internet. Baden-Baden: Nomos.

Mansell, R. (2012). Imagining the Internet. Oxford: Oxford University Press.

Mansell, R., \& Raboy, M. (Eds.). (2011). The Handbook of Global Media and Communication Policy. Malden: Wiley Blackwell.

McChesney, R. W. (2008). The Political Economy of Media. New York: Monthly Review Press.

McChesney, R. W. (2009). Public Scholarship and the Communications Policy Agenda. In A. M. Schejter (Ed.), ... And Communications for all (pp. 41-56). Lanham: Lexington.

McQuail, D. (1994). Media Policy Research. In C. J. Hamelink \& O. Linné (Eds.), Mass Communication Research: On Problems and Policies (pp. 39-51). Norwood: Ablex.

Melody, W. H., \& Mansell, R. (1983). The Debate over Critical vs. Administrative Research: Circularity or Challenge. Journal of Communication, 33(3), 103-116. doi:10.1111/j.14602466.1983.tb02412.x

Mueller, M. (1995). Why Communications Policy is Passing "Mass Communication" by. Critical Studies in Mass Communication, 12(4), 457-472.

Mueller, M. (2010). Networks and states. Cambridge: MIT Press.

Napoli, P. M., \& Friedland, L. (2016). US Communications Policy Research and the Integration of the Administrative and Critical Communication Research Traditions. Journal of Information Policy, 6, 41-65. doi:10.5325/jinfopoli.6.2016.0041

Noam, E. (1993). Reconnecting Communications Studies with Communications Policy. Journal of Communication, 43(3), 199-206. doi:10.1111/j.1460-2466.1993.tb01293.x 
Noam, E. (2009). Media Ownership and Concentration in America. Oxford: Oxford University Press.

Nordenstreng, K. (2004). Ferment in the Field: Notes on the Evolution of Communication Studies and its Disciplinary Nature. Javnost - The Public, 11(3), 5-17. doi:10.1080/13183222.2004.11008856

Picard, R. G. (2016). Isolated and Particularised: The State of Contemporary Media and Communications Policy Research. Javnost - The Public, 23(2), 135-152. doi:10.1080/13183222.2016.1162991

Pickard, V. (2013). Mending the Gaps. In K. Gates (Ed.), The International Encyclopedia of Media Studies. Volume VI: Media Studies Futures (pp. 1-18). Malden: Wiley Blackwell.

Pickard, V. (2015). America's Battle for Media Democracy. Cambridge: Cambridge University Press.

Pool, I. d. S. (1974). The Rise of Communications Policy Research. Journal of Communication, 24(2), 31-42. doi:10.1111/j.1460-2466.1974.tb00366.x

Price, M. E., Verhulst, S. G., \& Morgan, L. (2013). Routledge Handbook of Media Law. New York: Routledge.

Puppis, M. (2010). Media Governance. Communication, Culture \& Critique, 3(2), 134-149. doi:10.1111/j.1753-9137.2010.01063.x

Puppis, M., \& d'Haenens, L. (2012). Comparing Media Policy and Regulation. In F. Esser \& T. Hanitzsch (Eds.), Handbook of Comparative Communication Research (pp. 221-233). London: Routledge. 
Raboy, M., \& Padovani, C. (2010). Mapping Global Media Policy: Concepts, Frameworks, Methods. Communication, Culture \& Critique, 3(2), 150-169. doi:10.1111/j.17539137.2010.01064.x

Reinard, J. C., \& Ortiz, S. M. (2005). Communication Law and Policy: The State of Research and Theory. Journal of Communication, 55(3), 594-631. doi:10.1111/j.14602466.2005.tb02687.x

Schejter, A. M. \& Tirosh, N. (2016). A Justice-Based Approach for New Media Policy. Cham: Palgrave Macmillan.

Schulz, W., Valcke, P., \& Irion, K. (Eds.). (2013). The Independence of the Media and its Regulatory Agencies. Bristol: Intellect.

Simpson, S., Puppis, M., \& Van den Bulck, H. (Eds.). (2016). European Media Policy for the Twenty-First Century. London: Routledge.

Van den Bulck, H., Puppis, M., Donders, K., \& Van Audenhove, L. (Eds.). (forthcoming). The Palgrave Handbook of Media Policy Research Methods. Basingstoke: Palgrave Macmillan.

Voltmer, K. (2012). How Far Can Media Systems Travel? In D. C. Hallin \& P. Mancini (Eds.), Comparing Media Systems Beyond the Western World (pp. 224-245). Cambridge: Cambridge University Press.

Waisbord, S., \& Mellado, C. (2014). De-Westernizing Communication Studies. Communication Theory, 24(4), 361-372. doi:10.1111/comt.12044

Wasserman, H., \& de Beer, A. S. (2009). Towards De-Westernizing Journalism Studies. In K. Wahl-Jorgensen \& T. Hanitzsch (Eds.), The Handbook of Journalism Studies (pp. 428438). New York: Routledge. 
Zajácz, R. (2012). Fragmented Imperialism. International Communication Gazette, 74(1), 78-94. doi: $10.1177 / 1748048511426996$ 